\section{Temperature of Broccoli Florets at Time of Packaging Influences Package Atmosphere and Quality}

\author{
Charles F. Forney and Roger E. Rij \\ Horticultural Crops Research Laboratory, Agricultural Research Service, \\ U.S. Department of Agriculture, 2021 South Peach Avenue, Fresno, \\ CA 93727
}

Additional index words. Brassica oleracea, cooling, modified atmospheres, polymeric films

\begin{abstract}
Warm (20C) or cold (3C) broccoli florets (Brassica oleracea L., Italica Group) were sealed in bags of two types of nonperforated flexible polyvinylchloride film, TPM 87 or RMF 61, and kept at 5C for 7 days. Temperature of the warm florets cooled to $5 \mathrm{C}$ in $\approx 8$ hours. Warm broccoli had $40 \%$ to $50 \%$ more $\mathrm{CO}_{2}$ and $25 \%$ to $30 \%$ less $\mathrm{O}_{2}$ than cold broccoli in packages of both film types 6 hours after sealing. After 48 hours, however, concentrations of $\mathrm{CO}_{2}$ in bags of cold and warm broccoli had reached a steady state of $\approx 14.5 \%$ in TPM 87 bags and $6 \%$ in RMF 61 bags. Concentrations of $\mathrm{O}_{2}$ were more variable. After 48 hours, $\mathrm{O}_{2}$ concentrations were $\approx 2 \%$ to $4 \%$ in TPM 87 bags and $5 \%$ to $10 \%$ in RMF 61 bags. Initially, warm florets were rated lower for color, turgidity, and general appearance than initially cold ones after 7 days at $5 \mathrm{C}$. Objectionable off-odors were formed from florets held in TPM 87 packages that had $\mathrm{O}_{2}$ concentrations of $<1.5 \%$.
\end{abstract}

Atmosphere modification, by lowering $\mathrm{O}_{2}$ and/or increasing $\mathrm{CO}_{2}$ concentrations, has been shown to maintain quality and extend the storage life of many fresh commodities (Hardenburg, 1971; Hardenburg et al., 1986; Kader et al., 1989). Packaging techniques can be used to achieve these beneficial atmospheres. One technique, referred to as modified-atmosphere (MA) packaging, depends on the respiration rate of the commodity and the gas permeation properties of the packaging film to determine the package atmosphere composition (Kader et al., 1989; Labuza and Breene, 1989; Varriano-Marston, 1989). Both of these factors are influenced by temperature, concentrations of $\mathrm{O}_{2}$ and $\mathrm{CO}_{2}$ in the atmosphere, and humidity (Forney et al., 1989; Kader et al., 1989). If these environmental factors remain constant, the MA inside the package will come to steady state soon after sealing (Ballantine et al., 1988; Forney et al., 1989; Kader et al., 1989; Tomkins and Cumming, 1988). A properly designed package can maintain a desired atmosphere throughout the storage and marketing of a fresh commodity.

Rapid cooling of fresh produce following harvest is important for maintaining quality by slowing the rates of respiration and senescence (Brennan and Shewfelt, 1989; Ryan and Lipton, 1979). Icing is used on many fresh vegetables for rapid cooling and pre-

Received for publication 12 July 1990 . The authors thank Mann Packing for generously supplying broccoli florets used in this study. We also acknowledge the technical assistance of Cawley Carr in conducting gas analysis. The cost of publishing this paper was defrayed in part by the payment of page charges. Under postal regulations, this paper therefore must he hereby marked advertisement solely to indicate this fact. vention of water loss (Ryan and Lipton, 1979). However, with the development of precut vegetables for food service and institutional markets, iceless packages are more convenient and avoid the problem of water accumulation from melting ice in coolers (Patterson, 1989). With the departure from traditional icing, cooling of these fresh vegetables following harvest may be inadequate. However, quality deterioration at higher-thanrecommended temperatures may be slowed through the use of MA.

Broccoli has been traditionally cooled with package ice. In recent years there has been an increasing market for broccoli florets packaged without ice (Patterson, 1989). Broccoli responds favorably to MA of $1 \%$ $\mathrm{O}_{2}$ and/or $10 \% \mathrm{CO}_{2}$ (Lebermann et al., 1968; Lipton and Harris, 1974), which have been achieved through packaging in polymer films (Elkashif et al., 1983; Rij and Ross, 1987; Wang and Hruschka, 1977). These MA maintain the quality of broccoli held at 5 or $7.5 \mathrm{C}$ for longer periods than would be possible in air. However, temperature of broc-

Table 1. Changes in atmosphere composition in packages of broccoli florets over time as affected by package film type and temperature at the time of packaging.

\begin{tabular}{|c|c|c|c|c|c|c|c|}
\hline \multirow[b]{3}{*}{ Film type } & \multirow{3}{*}{$\begin{array}{l}\text { Temp } \\
\left({ }^{\circ} \mathrm{C}\right)\end{array}$} & \multicolumn{6}{|c|}{ Time after sealing (h) } \\
\hline & & \multicolumn{2}{|c|}{6} & \multicolumn{2}{|c|}{48} & \multicolumn{2}{|c|}{168} \\
\hline & & $\mathrm{O}_{2}$ & $\mathrm{CO}_{2}$ & $\mathrm{O}_{2}$ & $\mathrm{CO}_{2}$ & $\mathrm{O}_{2}$ & $\mathrm{CO}_{2}$ \\
\hline TPM 87 & $\begin{array}{r}20 \\
3\end{array}$ & $\begin{array}{l}11.1 \\
15.7\end{array}$ & $\begin{array}{l}5.9 \\
3.9\end{array}$ & $\begin{array}{l}2.3 \\
3.8\end{array}$ & $\begin{array}{l}14.6 \\
14.1\end{array}$ & $\begin{array}{l}3.0 \\
4.6\end{array}$ & $\begin{array}{l}15.2 \\
14.4\end{array}$ \\
\hline RMF 61 & $\begin{array}{r}20 \\
3\end{array}$ & $\begin{array}{l}12.0 \\
16.0\end{array}$ & $\begin{array}{l}4.8 \\
3.4\end{array}$ & $\begin{array}{r}5.0 \\
10.1\end{array}$ & $\begin{array}{l}6.0 \\
6.2\end{array}$ & $\begin{array}{r}6.7 \\
10.7\end{array}$ & $\begin{array}{l}5.0 \\
5.0\end{array}$ \\
\hline \multicolumn{8}{|c|}{ Significance } \\
\hline Film & & NS & $* *$ & * & $* * *$ & ** & $* * *$ \\
\hline Temp & & *** & $* * *$ & ${ }^{*}$ & NS & NS & NS \\
\hline$F \times T$ & & NS & NS & NS & NS & NS & NS \\
\hline
\end{tabular}

NS,*,*,***Nonsignificant or significant at $P=0.05,0.01$, or 0.001 , respectively, according to $\mathrm{F}$ test. 
Table 2. Effect of film type and temperature at the time of packaging on the quality of broccoli florets after 7 days at $5 \mathrm{C}$. Values represent the average ratings of the means of three replications.

\begin{tabular}{lcccccc}
\hline \hline & & \multicolumn{5}{c}{ Rating } \\
\cline { 2 - 7 } Film type & $\begin{array}{c}\text { Tcmp } \\
\left({ }^{\circ} \mathrm{C}\right)\end{array}$ & Odor & Decay & Color & Turgidity & $\begin{array}{c}\text { General } \\
\text { appearance }\end{array}$ \\
\hline TPM 87 & 20 & 7.8 & 8.6 & 7.8 & 7.3 & 7.3 \\
& 3 & 7.6 & 8.8 & 9.0 & 8.7 & 8.8 \\
RMF 61 & 20 & 8.8 & 8.3 & 7.5 & 7.4 & 7.0 \\
& 3 & 8.8 & 8.8 & 8.8 & 9.0 & 8.4 \\
Significance & & $* *$ & & & & NS \\
Film & & NS & NS & $* * *$ & NS & NS \\
Temp & & NS & NS & NS & NS & NS \\
F $\times$ T & & &
\end{tabular}

${ }^{2}$ Rating scale: odor, $9=$ normal, 1 = nauseating; decay, $9=$ none, $1=$ severe; color, $9=$ dark green, $1=$ yellow; turgidity, $9=$ turgid, $1=$ dry; general appearance, $9=$ excellent, $1=$ very poor.

NS,**,***Nonsignificant or significant at $P=0.01$ or 0.001 , respectively, according to F test.

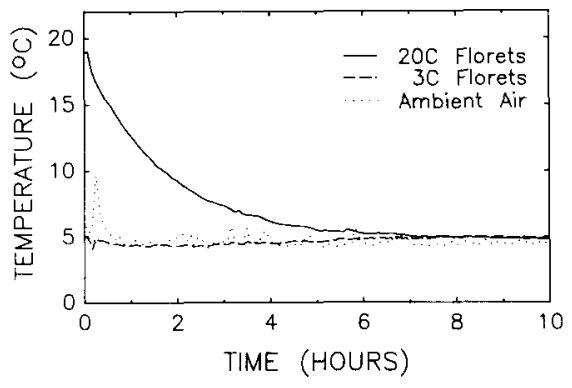

Fig. 1. Mean temperatures of broccoli florets packaged at 20C (warm) or 3C (cold) after indicated time at $5 \mathrm{C}$.

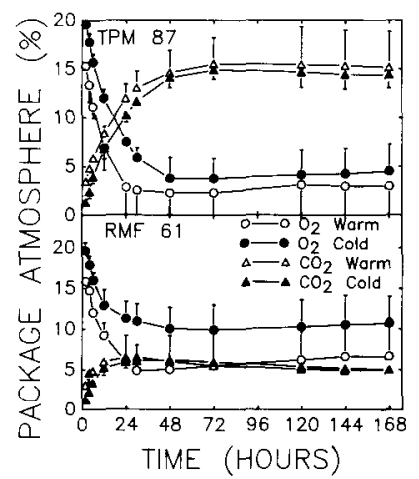

Fig. 2. Concentrations of $\mathrm{O}_{2}$ and $\mathrm{CO}_{2}$ over time in bags of two formulations of polyvinylchloride polymer films (TPM 87 and RMF 61) filled with broccoli florets that had been kept at 20C (warm) and $3 \mathrm{C}$ (cold) before being sealed and kept at $5 \mathrm{C}$ starting at time 0 . Each point is the mean of 12 packages \pm sE.

floret in each treatment. Holes to allow thermocouple wires into bags were sealed with silicon rubber caulking.

The atmosphere inside each package was sampled using a 1-ml gas-sampling syringe inserted through a septum made of silicon rubber caulking. Samples were taken 2, 4, $6,12,24,30,48,72,120,144$, and $168 \mathrm{~h}$ after packages were placed at SC. The $1-\mathrm{ml}$ gas samples were analyzed for $\mathrm{O}_{2}$ and $\mathrm{CO}_{2}$ concentration using a Shimadzu GC-8A gas chromatography (Shimadzu Scientific Instruments, Columbia, Md.) equipped with a thermoconductivity detector and a 1.9-m
CTR1 column (Alltech Assocs., Deerfield, Ill.).

Quality of broccoli florets was evaluated 7 days after packaging. Broccoli was removed from bags and evaluated for color, turgor, decay, and general appearance using a rating scale of 9 to 1 as described by Rij and Ross (1987). Odor was evaluated using a similar subjective scale based on the criteria of Wang and Hruschka (1977).

The experiment was a $2 \times 2$ factorial in a randomized complete-block design. The experiment was replicated three times and treatment means of each replication were treated as a block.

Warm broccoli (20C) packaged in PVC bags cooled slowly after being placed at $5 \mathrm{C}$ (Fig. 1). In $\approx 8 \mathrm{~h}$, the temperature of warm florets was similar to that of florets packaged cold and only $\approx 10.3 \mathrm{C}$ warmer than the ambient temperature. During this time, $\mathrm{CO}_{2}$ concentrations in the packages were increasing and $\mathrm{O}_{2}$ concentrations were decreasing more rapidly in the warm than in the cold broccoli in both film types (Fig. 2). After 6 h, $\mathrm{O}_{2}$ concentrations were $25 \%$ to $30 \%$ lower in broccoli packaged warm than cold (Table 1). At this time, however, packages of RMF 61 did not differ significantly in $\mathrm{O}_{2}$ concentration from packages of TPM 87, even though the $\mathrm{O}_{2}$ transmission rate of RMF 61 is $70 \%$ higher than that of TPM 87. The respiration rate of broccoli is more than 10-fold higher at 20C than at 3C (Kader et al., 1989). These higher respiration rates of the warm broccoli for the first $8 \mathrm{~h}$ until it cooled to the temperature of the cold florets appears to have had a greater effect on the modification of the package atmosphere than the film permeation properties. Concentrations of $\mathrm{CO}_{2}$ were $40 \%$ to $50 \%$ higher in broccoli packaged warm than cold and were significantly different between film types. The $\mathrm{CO}_{2}$ transmission rate for RMF 61 is over six times that for TPM 87, which resulted in less $\mathrm{CO}_{2}$ accumulation during the initial $6 \mathrm{~h}$ following sealing.

After $48 \mathrm{~h}$, concentrations of $\mathrm{CO}_{2}$ in bags to the same steady state. Concentrations of $\mathrm{CO}_{2}$ in TPM 87 bags were $\approx 14.5 \%$ and in RMF 61 bags $\approx 6 \%$ and did not change significantly during the remainder of the exof initially cold and warm broccoli had come periment (Fig. 2, Table 1). At this time, the differences in atmosphere composition were due to differences in film permeability, since respiration rates would be expected to be similar. Concentrations of $\mathrm{O}_{2}$ tended to be more variable. In TPM 87, $\mathrm{O}_{2}$ levels after $48 \mathrm{~h}$ were not significantly different between broccoli packed warm or cold and ranged between $\approx 2 \%$ and $4 \%$. In RMF 61 bags, however, $\mathrm{O}_{2}$ levels remained $4 \%$ to $5 \%$ higher in cold-packed broccoli than in warm throughout the experiment. This difference remained significant up to $72 \mathrm{~h}$ after sealing.

In previous studies, atmosphere modification in packages of whole heads of broccoli wrapped in TPM 87 ranged from $8 \%$ to $14 \% \mathrm{O}_{2}$ and $7 \%$ to $10 \% \mathrm{CO}_{2}$ (Forney et al., 1989; Rij and Ross, 1987), which was 5\% to $10 \%$ more $\mathrm{O}_{2}$ and $4 \%$ to $5 \%$ less $\mathrm{CO}_{2}$ than in the atmospheres in bags of broccoli florets. The respiration rate of florets may have been higher than that of whole heads because of the removal of stem tissue that probably would have a much lower rate of respiration than flower buds. The higher respiration rate would explain why florets produced a greater modification of package atmosphere than observed in whole heads and indicates that a more permeable film is needed to obtain similar MA in packages of florets than in whole heads.

Quality of broccoli florets was significantly reduced when kept warm overnight before packaging. This reduction in quality was reflected by lower ratings for color, turgidity, and general appearance in broccoli packed warm rather than cold (Table 2). Film type, including vented bags (data not shown), had no effect on these characteristics. Keeping the florets 17 to $18 \mathrm{~h}$ at $20 \mathrm{C}$ had caused noticeable acceleration of senescence when florets were evaluated after 7 days of storage at $5 \mathrm{C}$. The higher rate of respiration at $20 \mathrm{C}$ may have aided this acceleration of senescence. In addition, the vapor pressure deficit in the storage conditions for the warm broccoli before packaging was three times higher than that for the cold, resulting in increased water loss and the lower turgidity rating (Table 2). Brennan and Shewfelt (1989) reported that delays in cooling as short as $3 \mathrm{~h}$ reduced broccoli quality. These observations demonstrate the importance of good precooking and temperature management in order to maintain broccoli quality.

Objectionable off-odors at times were formed by broccoli bagged in TPM 87 . These odors were present only in bags that contained less than $\approx 1.5 \% \mathrm{O}_{2}$. Off-odors have developed in other studies in which broccoli was stored in $10 \%$ or higher concentrations of $\mathrm{CO}_{2}$ in combination with $2.5 \%$ or less $\mathrm{O}_{2}$ (Ballantine et al., 1988 Kasmire et al., 1974; Makhlouf et al., 1989). It appears that these odors become stronger as $\mathrm{O}_{2}$ concentrations decrease or storage times increase. The avoidance of conditions that induce these objectionable odors should be a primary concern in developing a MA package for broccoli.

From these results it appears that the composition of steady-state atmospheres established in film-wrapped packages of broccoli 
is not significantly affected by broccoli temperature at the time of packaging. However, the effect of delayed cooling on broccoli quality may be significant, depending on the time elapsed before packaging and cooling. The more rapid atmosphere modification in the packages of warm broccoli may compensate, at least partly, for the detrimental effect of the warm temperature in situations in which the exposure to relatively high temperatures is shorter than $17 \mathrm{~h}$.

\section{Literature Cited}

Ballantyne; A., R. Stark, and J.D. Selman. 1988. Modified atmosphere packaging of broccoli florets. Intl. J. Food Technol. 23:353-360,

Brennan, P.S. and R.L. Shewfelt. 1989. Effect of cooling delay at harvest on broccoli quality during postharvest storage. J. Food Qual. 12:1322.

Elkashif, M. E., D.J. Huber, and M. Sherman. 1983. Delaying deterioration of broccoli and cucumber using polymeric films. Proc. Fla. State Hort. Soc. 96:332-335.

Forney, C. F., R.E. Rij, and S.R. Ross. 1989. Measurement of broccoli respiration rate in filmwrapped packages. HortScience 24(1):111-113.

Hardenburg, R.E. 1971. Effect of in-package environment on keeping quality of fruits and vegetables. HortScience 6(3):198-201.

Hardenburg, R. E., A.E. Watada, and C.Y. Wang. 1986. The commercial storage of fruits, vegetables, and florist and nursery stocks. U.S. Dept. Agr., Agr. Hdbk. 66.

Hernandez, R., J. Giacin, and A. Baner. 1986. Measuring the aroma barrier properties of polymeric packaging materials. Packaging Technol. 16(4):12-15.

Kader, A. A., D. Zagory, and E.L. Kerbel. 1989. Modified atmosphere packaging of fruits and vegetables. Crit. Rev. Food Sci. Nutr. 28(1):130.

Kasmire, R. F., A.A. Kader, and J.A. Klaustermeyer. 1974. Influence of aeration rate and atmospheric composition during simulated transit on visual quality and off-odor production by broccoli. HortScience 9(3):228-229.

Labuza, T.P. and W.M. Breene. 1989. Applications of "active packaging" for improvement of shelf-life and nutritional quality of fresh and extended shelf-life foods. J. Food Preserv. 13:169.

Lebermann, K. W., A.I. Nelson, and M.P. Steinberg. 1968. Postharvest changes of broccoli stored in modified atmosphere; I. Respiration of shoots and color of flower heads. Food Technol. 22:487-490.

Lipton, W.J. and C.M. Harris. 1974. Controlled atmosphere effects on the market quality of stored broccoli. J. Amer. Soc. Hort. Sci. 99:200-205.

Makhlouf, J., F. Castaigne, J. Arul, C. Willemot, and A. Gosselin. 1989. Long-term storage of broccoli under controlled atmosphere. HortScience 24(4):637-639.

Patterson, P. 1989. Iceless packaging is gaining ground. Produce News 13:H1 Apr. p. 4.

Rij, R.E. and S.R. Ross. 1987. Quality retention of fresh broccoli packaged in plastic films of defined $\mathrm{CO}_{2}$ transmission rates. Packaging Technol. 17(3):22-23.

Ryan, A.L. and W.J. Lipton. 1979. Handling, transportation and storage of fruits and vegetables. 2nd ed. AVI, Westport, Conn.

Tomkins, R.B. and B.A. Cumming. 1988. Effect of pre-packaging on asparagus quality after simulated transportation and marketing. Scientia Hort. 36:25-35.
Varriano-Marston, E. 1989. Technical challenges in commercializing controlled atmosphere packaging. Tappi J. 72(6):111-113.
Wang, C.Y. and H.W. Hruschka. 1977. Quality maintenance in polyethylene-packaged broccoli. U.S. Dept. Agr. Mktg. Res. Rpt. 1085. 